\title{
HISTOLOGICAL AND IMMUNOHISTOCHEMICAL CHANGES OF THE THYROID GLAND DURING THE FOETAL AND POST- NATAL PERIOD OF DEVELOPMENT IN INDIGENOUS LARGE WHITE CROSSBRED PIGS
}

\author{
C. O. IGBOKWE \& D. N. EZEASOR \\ Department of Veterinary Anatomy, Faculty of Veterinary Medicine, \\ University of Nigeria, Nsukka, Nigeria
}

\begin{abstract}
Summary
Igbokwe, C. O. \& D. N. Ezeasor, 2015. Histological and immunohistochemical changes of the thyroid gland during the foetal and postnatal period of development in indigenous Large White crossbred pigs. Bulg. J. Vet. Med., 18, No. 4, 313-324.

The present study was carried out to ascertain the morphometric, histological and immunohistochemical changes (expression of calcitonin and somatostatin) in the thyroid gland of indigenous local pig crosses during the foetal and postnatal period of development. A total of thirty foetal thyroids (40) grouped into early and late foetal period, fifteeen (15) prepubertal and ten (10) pubertal thyroids obtained from slaughtered pigs in the local abattoir were used. Histomorphometrically, all the measured parameters increased with development in all thyroid age group. The mean values were significantly different at $\mathrm{P}<0.05$ among ages. Histologically, significant age-related variations in the structure of the foetal and postnatal thyroids were observed in the follicles, colloid, colloid vacuoles, follicular cells and interfollicular connective tissue. Calcitonin was demonstrated in the foetal and postnatal parafollicular cells, while somatostatin was only localised in the pubertal parafollicular cells. The study provides strong evidence of thyroid functionality during the late foetal period that changes with age during the development.
\end{abstract}

Key words: foetal, histology, imunohistochemistry, pig, postnatal, thyroid gland

\section{INTRODUCTION}

The thyroid gland is the first glandular structure to form. It develops as a ventral midline endodermal diverticulum from the floor of the foregut at a level between the first and second pharyngeal arches. The caudal end of the thyroid primordial structure extends ventrally and caudally into the underlying mesoderm. Initially, it re- mains attached to the foregut, by the thyroglossal duct (Nooden \& De Lahunta, 1985). The gland is unique among vertebrate endocrine organs in that it stores secretory product (thyroid hormones) extracellularly (Braverman \& Cooper, 2012). The thyroid gland produces three hormones, each of which is essential in nor- 
mal metabolism and homeostasis. Thyroxine (tetraiodothyronine, T4) and triiodothyronine (T3) are synthesized and secreted by the follicular cells. The effects of the thyroid hormones on growth and metabolism in all stages of mammalian development are well documented (Janini et al., 1995; Huszenica et al., 2002; Capen \& Martin, 2003). These hormones have important effects on cell proliferation, differentiation, and migration as well as growth and metabolism of embryos (Krees et al., 2009). They are also important in normal reproduction, productive performance such as growth, milk and hair fibre production in domestic animals and hence affect farm animal productivity (Tondini, 2007). The thyroid also produces calcitonin from the parafollicular cells that regulates calcium metabolism. Also in several mammalian thyroids a large number of other regulatory peptides are also produced in secretory granules of parafollicular cells in addition to calcitonin. Some of them are co-localised with calcitonin in the parafollicular cells and they include somatostatin, chromogranin, katacalcin I and II, gastrin-releasing peptide, thyroliberin and halodermin (Ahren, 1991; Sawicki, 1995). It has been established that somatostatin inhibits TSHstimulated thyroid hormone secretion as demonstrated both in vivo in mice and in man. Somatostatin has also been shown to inhibit TSH-stimulated cyclic AMP production in human thyroids (Ahrẻn, 1991). Somatostatin inhibits the secretion of almost all hormones from the gastrointestinal tract. It also inhibits the growth of normal and neoplastic tissues (Schally, 1987). The presence of somatostatin immunoreactivity in $\mathrm{C}$ cells of the thyroid is well established and a marked variation in immunoreactivity of thyroid $\mathrm{C}$ cells was shown from species to species and during development of the gland (Kameda, 1984).

The thyroid gland shows a marked variation in structural components according to the functional status of the gland during development and in response to environmental influence. It differs among animal species. Also, the parafollicular cells undergo significant alterations during prenatal and post natal development. This alteration is related to the number of cells, morphology and hormone storage in the cells (Kameda, 1984). A good number of published articles on thyroid structure and its development are mainly from work carried out in invertebrates, murines (mouse, rat), reptiles, zebra fish and humans (Fujita, 1975; Rupik, 2011). However some studies in pigs (Tomonari, 1959; Parker et al., 1980; Majdic et al., 1993) focused more on histology, morphometry, and hormonal profile in postnatal pigs with scant information on foetal and postnatal thyroid structure. Madjic et al., (1993) studied immunohistology of calcitonin and somatostatin expression in thyroids of only postnatal pigs. Even so, such study in pigs reared in the humid tropical environment is lacking. It is possible that there are variations in structure of thyroids during development in tropical breeds due to variation in genome, environmental conditions and husbandry methods. Pigs are currently considered one of the major animal species used in translational research and are increasingly being used as alternative to dog or monkey as non rodent species of choice in preclinical toxicological testing of pharmaceuticals and in endocrine-disruption experiments (Swindle et al., 2012).

The aim of the present study is to provide information on the histology and morphometry of the thyroid structure along with immunohistochemical expres- 
sion of calcitonin and somatostatin bioactive peptides during the foetal and postnatal period in pig.

\section{MATERIALS AND METHODS}

A total of thirty foetal thyroids (30) grouped into early foetal period (18) and late foetal period (12) based on estimated age, fifteen (15) prepubertal and ten (10) pubertal thyroids, obtained from slaughtered pigs in the local abattoir in Nsukka town, Nigeria were used for this study. The animals were certified by competent veterinarians to be apparently healthy before slaughter. The foetuses were obtained from inadvertently slaughtered pregnant pigs. The foetal age was estimated according to the chart provided for age determination in several domestic animals by McGeady et al., (2006). The postnatal age was estimated from the records kept by the pig farmers and by dentition. The estimated age ranges of the early foetal, late foetal, pre-pubertal and pubertal stages of Large White pigs were 45-90 days, 85110 days, 2-4 months and 1-3 years respectively. The average weight of the foetal pigs (45-110 days) and postnatal pigs (2 months-3 years) were $0.5 \mathrm{~kg}$ and 28.2 $\mathrm{kg}$ respectively. Female animals (including foetuses) were not considered in this study to eliminate fluctuations in follicular cell morphology caused by different reproductive phases, especially in the postnatal animals (Agrawal et al., 1986).

\section{Histological procedure}

After slaughter, the thyroid gland lobes were immediately excised from the ventral mid-line of the neck free of superficial fascia and muscles. Thin tissue slices were taken from different parts of each thyroid lobe and the isthmus. However sections of central portions of thyroid lobes were se- lected for morphometric analysis, since central portions of thyroid lobes have been shown to be representative of whole tissue (Denef et al., 1979). Tissue slices were fixed in $10 \%$ neutral buffered formalin processed routinely for light microscopy and sections were cut at $6 \mu \mathrm{m}$ thickness. Some of the sections were stained with haematoxylin and eosin, others with Periodic Acid-Schiff (PAS). Several selected $\mathrm{H} \& \mathrm{E}$ and PAS stained sections were used to obtain some morphometric parameters of the thyroid gland components at various age of development. An ocular micrometer gauge calibrated with a stage micrometer was used to obtain values of these parameters under a light microscope at $\times 400$ magnification. Photomicrographs were prepared with Axiom Vision $\AA$ digital camera (Germany) attached to a microscope.

\section{Immunohistochemical procedure}

Thyroid glands of foetal and postnatal period were cut into pieces and fixed in $10 \%$ neutral buffered formalin, processed in paraffin wax and serially sectioned at $6 \mu \mathrm{m}$ thickness. In the paraffin sections immunochistochemical reactions were perfomed on serial sections using Labelled Streptavidin-Biotin-Peroxidase method (LSAB ${ }^{\circledR}$ kit, DAKO, Glostrup, Denmark). Following dewaxing and rehydration of sections, endogenous peroxidase activity was blocked by incubation for 15 min in $3 \% \mathrm{H}_{2} \mathrm{O}_{2}$ in methanol. After rinsing in distilled water, antigen retrieval was carried out by Heat-induced epitope method (HIER) (Key \& Boenisch, 2010) for calcitonin antibody only and rinsed in phosphate buffered saline for $5 \mathrm{~min}$. Thereafter some slide sections were incubated by $\operatorname{LSAB}{ }^{\circledR}$ staining method with the following primary antibodies: 1) polyclonal rabbit anti-human calcitonin (Code $\mathrm{N}$ 
1552, Dako, Denmark) with dilution of 1:300 for $30 \mathrm{~min}$; 2) polyclonal rabbit anti-human somatostatin (Code A 0566, Dakocytomation) with dilution of $1: 400$ for $1 \mathrm{~h}$ following manufacturers's instructions. Tissue sections were covered with biotinylated linked secondary antibody following user's instructions, left for 15 min and returned to PBSA for $10 \mathrm{~min}$. Thereafter 1-2 drops of streptavidin peroxidase were applied and left for $15 \mathrm{~min}$. Sections were incubated with DAB chromogen liquid following manufacturer's instructions for 3-5 min. Slides were counterstained with Mayer's haematoxylin for few seconds, dehydrated in graded ethanol, cleared in xylene and mounted with Entellan ${ }^{\circledR}$. Selected sections were viewed and photographed with Olympus microscope (Japan) with Axiom ${ }^{\circledR}$ digital camera attachment. For negative controls, the incubation of sections with primary antibody was omitted and this completely abolished immuno-labelling. Also, thyroid tissue present in the sections examined served as internal controls, as well as canine thyroid and pancreas stained for calcitonin and somatostatin respectively. The number of calcitonin positive cells and somatostatin positive cells in each age group were established per observation field.

\section{Statistical analysis}

Histometric data obtained were presented as mean \pm SEM and analysed statistically using analysis of variance. Duncan's multiple range test was used to separate variant means, at significance level $\mathrm{P}<0.05$.

\section{RESULTS}

Histologically, the thyroid gland of early foetal period (45-80 days) showed a well differentiated capsule composed of fine collagenous tissue, fibroblasts and few vascular elements. Trabeculae containing connective tissue septa, vascular elements and nerves penetrated the parenchyma and distinct pseudo-lobules were present.

These lobules contained few cells organised into small follicles, but in some zones of gland, these cells in cords or plates, were surrounded by connective tissue cells, fibres and rudimentary vascular sinuses (Figs. $1 \& 2$ ). These differentiating follicles did not contain any stained colloid in their lumen and were PAS negative (Fig. 3). The most striking feature at this age is the predominance of large amount of cellular elements as compared to colloid. Smallest follicles had about 47 presumptive follicular cells, some small follicles possessed about 12-15 cells and in other small ones about 20-25 cells were encountered. Most of the epithelial follicular cells were cuboidal, but columnar cells were occasionally seen in the central zone of the thyroid sections. In the foetal age of 85-119 days the general histological architecture was maintained with more distinct pseudo-lobules, increased connective tissue elements, blood vessels, lymphatics and nerves. Numerous smallsized follicles intermingled with few medium and large-sized ones (Fig. 4). The small follicles were predominantly found in the periphery and sometimes interposed amongst profiles of medium and large follicles. The small follicles contained about 19-15 cells, the medium follicles about 20-25 cells, while about 30-35 cells were present in the large follicles. Copious perifollicular vascular sinuses and connective tissue elements were strikingly encountered around each follicle.

Some follicles contained faintly stained colloid-like materials especially in the small follicles (Fig. 5). These follicles 
with colloid-like materials were weakly PAS positive (Fig. 6). In the prepubertal thyroids, there was further increase in the connective tissue and cellular components. Follicles of varying sizes were present, with large follicles predominantly close to the capsule while medium and small-sized follicles were in the central zone (Fig. 7). Vascular elements differed from the typical blood sinuses seen in
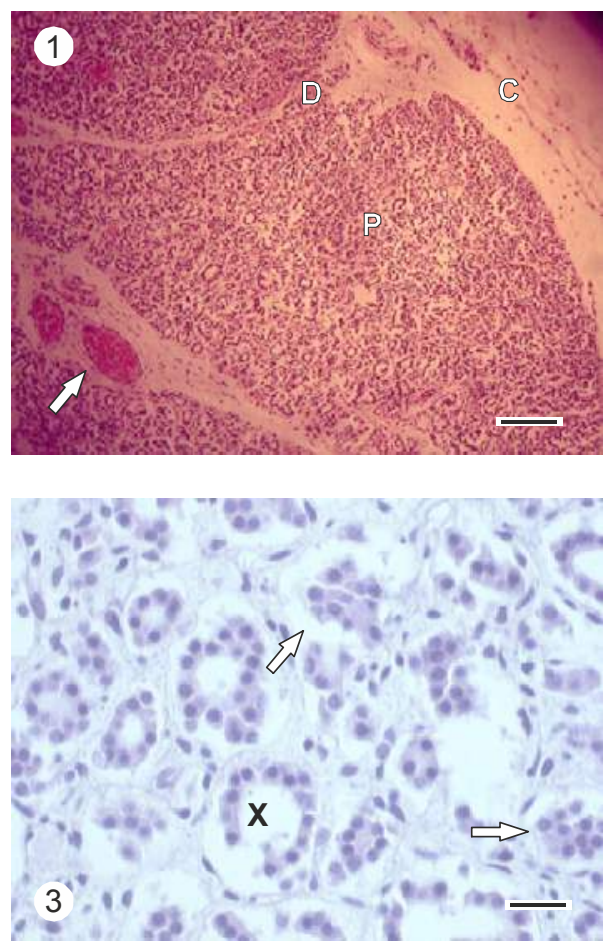

foetal age. All follicles irrespective of size contained eosinophilic colloid material that was strongly PAS-positive (Fig. 8). Colloid vacuoles were present in some small follicles in the centre. Parafollicular cells were encountered in clusters in interfollicular position and between follicular cells. In the pubertal thyroid in addition to the features seen previously, the colloid increased in the follicles over cellular
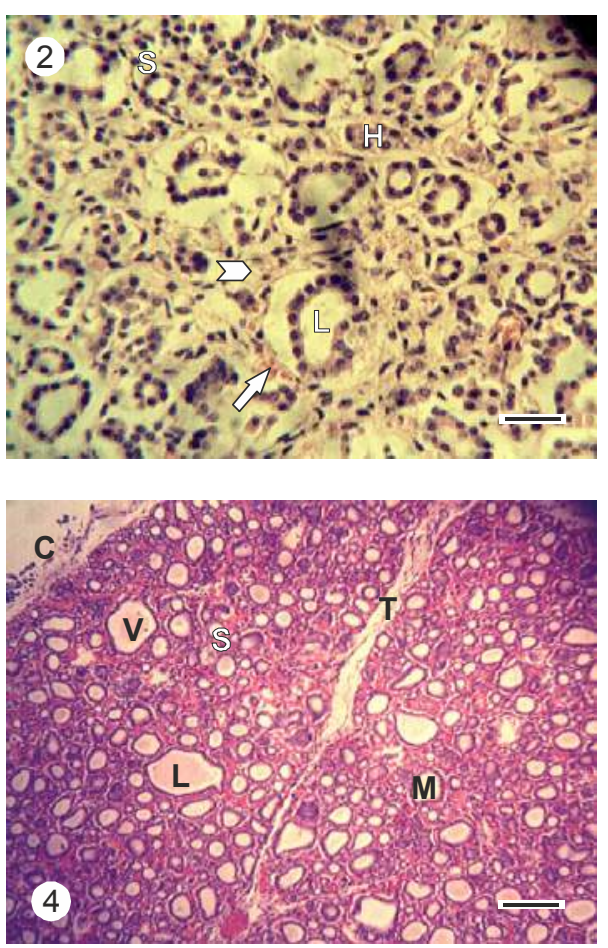

Fig. 1. Photomicrograph of foetal pig thyroid (45-80 days) showing developing capsule (C) and parenchyma (P) containing numerous immature small follicles. The lobular divisions (D) by septa from capsule are obvious and septa carry vessels and nerves (arrow), $\mathrm{H} \& \mathrm{E}$, bar=80 $\mu \mathrm{m}$. Fig. 2 . Higher magnification showing numerous irregular small follicles and cords of cells $(\mathrm{H})$ without colloid in the follicular lumen (L); follicular cells are 4-7 in smallest follicles (S). Perifollicular vascular sinuses (arrow) and scant interfollicular connective tissue (arrowhead) are apparent, H \& E, bar=20 $\mu \mathrm{m}$. Fig. 3. Photomicrograph of foetal pig thyroid (45-80 days), showing an overview of the thyroid parenchyma with well-developed interlobular septa (X) containing vascular elements amongst connective tissue fibre. Numerous small structures recognisable as follicles are present at this stage but no PAS positive colloid, PAS, bar $=40 \mu \mathrm{m}$. Fig. 4. Photomicrograph of foetal pig thyroid $(85-110$ days) showing gland with well developed capsule $(\mathrm{C})$, interlobular septa $(\mathrm{T})$ vessels, lymphatics and nerves, numerous small follicles (S) with few medium (M) and large follicles (L) containing little or no colloid in their lumen (V) that was poorly eosinophilic in staining, $\mathrm{H} \& \mathrm{E}$, bar=40 $\mu \mathrm{m}$. 

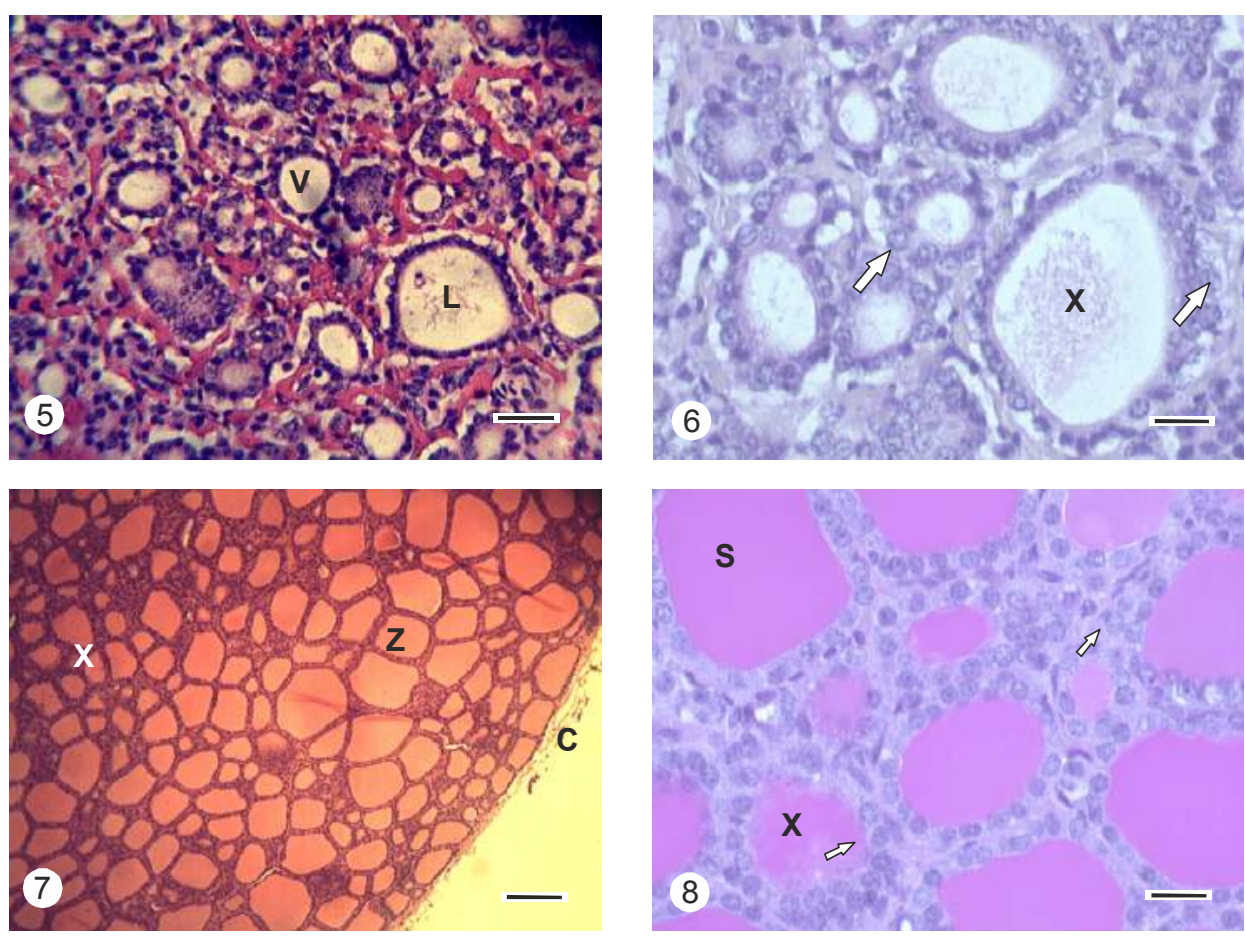

Fig. 5. Photomicrograph of foetal pig thyroid (85-110 days), showing highly abundant perifollicular blood vessels (sinuses) (V); the follicular cells around the lumen are about 25-35 cells in the large follicles (L), H \& E, bar=20 $\mu \mathrm{m}$. Fig. 6. Photomicrograph of foetal pig thyroid (85-110 days), showing weakly PAS-positive (X) colloid in the lumen of all follicular sizes. Note large parafollicular cells (arrow), PAS, bar $=40 \mu \mathrm{m}$. Fig. 7. Photomicrograph of prepubertal pig thyroid gland $(2-4$ months), showing thyroid gland with well developed parenchyma containing large follicles predominantly in the outer zone $(\mathrm{Z})$ closer to the capsule (C) and small and medium-sized follicles in the inner zone (X), H \& E bar=40 $\mu$ m. Fig. 8. Photomicrograph of pig thyroid (2-4 months) showing heterogenous PAS-positive colloid follicles, some follicles stained moderately (X), while others showed strong PAS-positive colloid (S). Lightly or pale-stained parafollicular cells are evident (arrows), PAS, bar $=20 \mu \mathrm{m}$.

elements with peripheral vacuolation in few of them. Many large highly dilated irregular follicles were present. Most follicles were distended with strongly stained colloid. In some zones of the thyroid parenchyma, there were islands of closely packed epithelial cells without a definite arrangement assumed to be hyperplastic changes of the gland (Fig. 9 A, B).

Histometrically, all the measured parameters (follicular diameter of small, medium and large-sized follicles, capsule thickness and cell height) increased with development in all thyroid age group. The mean values were significantly different at $\mathrm{p}<0.05$ in all age groups during development (Table 1).

Immunohistochemical staining to localise calcitonin and somatostatin in parafollicular (C) cells demonstrated moderate immunopositive reactivity to calcitonin antibody in foetal pig thyroid age groups (45-80 days and 85-110 days) and few cells were stained (Fig. 10). These calci- 

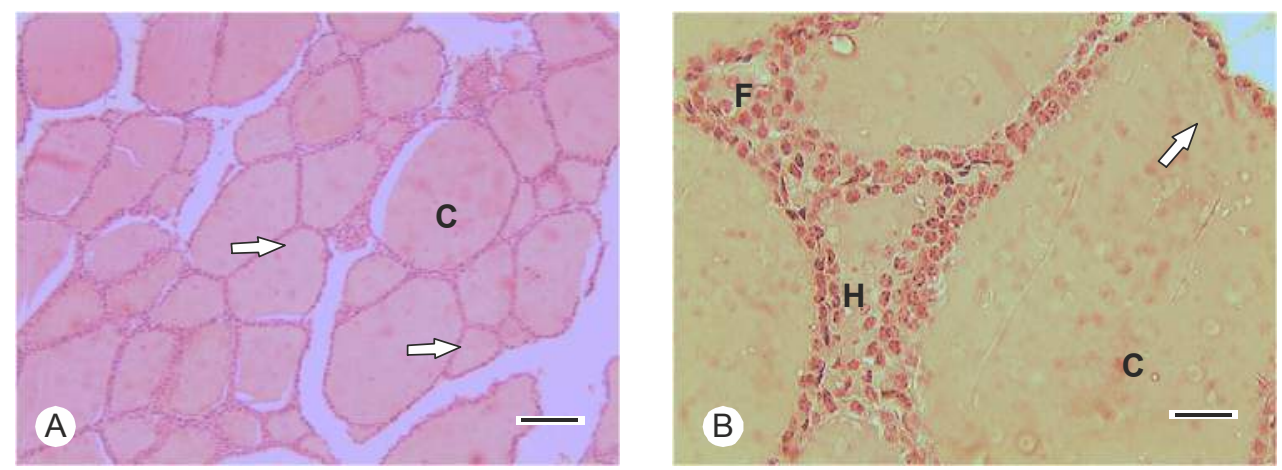

Fig. 9. A. Photomicrograph of pubertal pig thyroid (1-2 years). The profile of follicles in the parenchyma showed further distension of the follicles (arrow) by colloid (C), colloid droplets were rare, $\mathrm{H} \& \mathrm{E}$, bar $=40 \mu \mathrm{m}$; B. At higher magnification, areas of follicular hyperplasia $(\mathrm{H})$ and fibrosis $(\mathrm{F})$ were commonly seen in several older animals and flat (squamous) cells (arrow) surrounded the colloid (C), H \& E, bar $=20 \mu \mathrm{m}$.

Table 1. Histometric changes in the pig thyroid gland during foetal and postnatal growth (mean \pm SEM)

\begin{tabular}{lccccc}
\hline $\begin{array}{l}\text { Develop- } \\
\text { mental age }\end{array}$ & $\begin{array}{c}\text { Small follicu- } \\
\text { lar diameter } \\
(\mu \mathrm{m})\end{array}$ & $\begin{array}{c}\text { Medium follicu- } \\
\text { lar diameter } \\
(\mu \mathrm{m})\end{array}$ & $\begin{array}{c}\text { Large follicu- } \\
\text { lar diameter } \\
(\mu \mathrm{m})\end{array}$ & $\begin{array}{c}\text { Capsule } \\
\text { thickness } \\
(\mu \mathrm{m})\end{array}$ & $\begin{array}{c}\text { Cell height } \\
(\mu \mathrm{m})\end{array}$ \\
\hline $\begin{array}{l}\text { Foetal period } \\
\text { 45-80 day }\end{array}$ & $15.92^{\mathrm{a}} \pm 0.2$ & $16.75^{\mathrm{a}} \pm 1.2$ & $16.64^{\mathrm{a}} \pm 0.1$ & $81.93^{\mathrm{a}} \pm 0.8$ & $4.85^{\mathrm{a}} \pm 0.3$ \\
$85-110$ day & $23.34^{\mathrm{b}} \pm 0.2$ & $35.27^{\mathrm{b}} \pm 0.3$ & $59.22^{\mathrm{b}} \pm 0.3$ & $81.93^{\mathrm{a}} \pm 0.9$ & $5.85^{\mathrm{b}} \pm 0.1$ \\
\hline Postnatal period & & & & \\
Pre-puberty & $25.38^{\mathrm{c}} \pm 1.1$ & $53.03^{\mathrm{c}} \pm 0.4$ & $79.51^{\mathrm{c}} \pm 0.5$ & $139.41^{\mathrm{c}} \pm 0.2$ & $6.09^{\mathrm{c}} \pm 0.1$ \\
Puberty & $38.15^{\mathrm{d}} \pm 0.3$ & $58.23^{\mathrm{d}} \pm 0.1$ & $87.21^{\mathrm{d}} \pm 0.3$ & $142.38^{\mathrm{d}} \pm 0.4$ & $5.32^{\mathrm{d}} \pm 0.1$ \\
\hline
\end{tabular}

Means in the same column with different superscript are significantly different at $\mathrm{P}<0.05$.

tonin-positive cells increased with foetal age. In the pre-pubertal (2-4 months) and pubertal thyroids (1-3 years) strong immunopositive staining to calcitonin antibody was demonstrated in all sections, being widely distributed around the edge of follicles, some areas contained few or no C-cells (Fig. 11). Somatostatin-positive cells were not encountered in foetal thyroid sections of all ages. However, weakly stained somatostatin-positive C-cells in the pre-pubertal and pubertal thyroid sections were observed. They were relatively rare compared to calcitonin-positive cells.
They were also not evenly distributed in thyroid sections in discrete areas of the thyroid (Fig. 12).

\section{DISCUSSION}

The present study used foetal, prepubertal and pubertal Large White pig crosses to provide information on the comparative development, morphology and histochemistry of the thyroid gland. It is wellestablished that the role of the thyroid gland in vertebrates is crucial to the general metabolism of the organism and the 


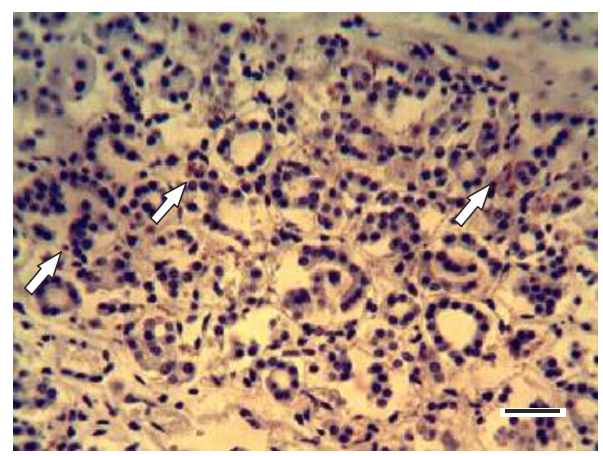

Fig. 10. Photomicrograph of immunohistochemical sections of foetal pig thyroid (45-80 days) showing very few weakly stained calcitonin-positive parafollicular cells (arrows), bar $=20 \mu \mathrm{m}$.

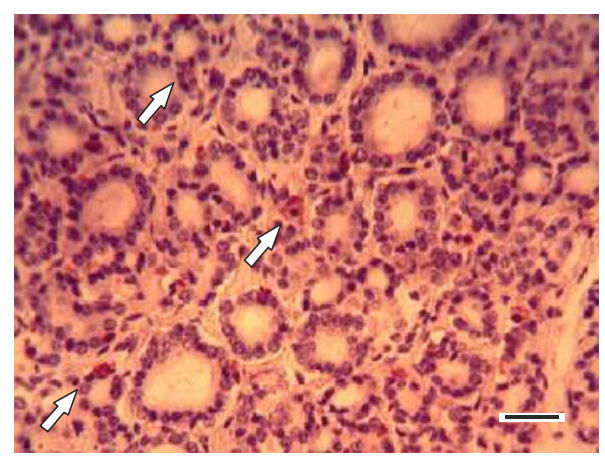

Fig. 11. Photomicrograph of immunostained sections of pubertal pig thyroid showing strong immunoreactivity of more parafollicular cells to calcitonin antibody (arrows), bar $=20 \mu \mathrm{m}$.

expression of this role is dependent on the age, nutrition and environment, especially climatic factors. It is therefore reasonable to expect certain structural and functional variations which modulate the function of the thyroid during development. Some authors have already shown that there are wide species variations in location, size, presence or absence of isthmus and histological structure in domestic animals (Venzke, 1975; Roy \& Yadava, 1975). In addition ultrastructural and histochemical variations have been demonstrated in several mammals and have been reviewed extensively by Fujita (1975). However concise information is lacking on the histology of developmental thyroid and immunohistochemical features of the parafollicular cells with regard to the presence of regulatory peptides during development in pigs, particularly the local cross breeds.

Histologically, significant variations in the structure of the thyroid in the foetal and postnatal thyroids were observed in this study. The size (follicular diameter, capsule thickness and cell height), number of follicles and its follicular cells increased as the thyroid matured. The present study is in agreement with the histological and morphometric findings in the thyroids of mice (Blumenthal, 1955), Asiatic water buffalo (Mathur, 1971), goats (Roy et al., 1978) and European bisons (Sawicki et al., 1992). These variations in histological features and morphometry with developmental age could result from several internal and environmental factors influencing thyroid development and function. Initially in the early foetal period (45-80 days), they showed no PAS positive material but in the late foetal period (85-110 days), there was progression to a

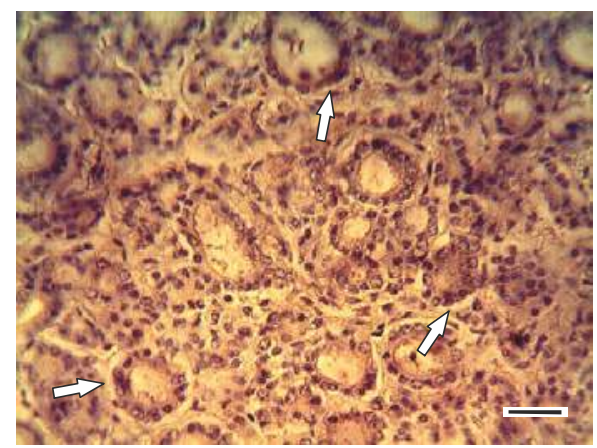

Fig. 12. Photomicrograph of pubertal pig thyroid showing few weakly stained somatostatin-positive parafollicular cells (arrows), bar $=20 \mu \mathrm{m}$. 
faintly PAS positive material which increased in intensity by the pre-pubertal period. The presence of many cuboidal and some columnar cells along with colloid in the late foetal stage follicles indicated onset of thyroid activity in the synthesis of thyroglobulin. The presence of colloid was reported in prenatal cattle and buffaloes by Schafie \& Mashaly (1974) and Ranjan et al., (2011) respectively. A PAS-positive colloid was detected in human foetal thyroid at $13^{\text {th }}-14^{\text {th }}$ week of gestation (Gaikwad et al., 2012). It was also observed in the foetal thyroids of goats at 30 days of gestation (Igbokwe, 2013). The present finding along with the earlier reports of other researchers suggest that the appearance of developing follicles and stainable colloid is variable amongst domestic animals: depending on the gestational length but most domestic animals probably secrete colloid prenatally. This opinion is further supported by the report of Miskavitch (1957) in birds and several mammals: camels (Badawy et al., 1978) and rabbits (Soliman et al., 2005). Peripheral colloid droplets (vacuoles) were rarely seen in the foetal thyroids but were more frequently seen in the follicles of the pre-pubertal and pubertal thyroids, suggesting intense thyroid stimulation and activity at this period of development.

According to Roy et al. (1978), very active follicles were lined by cells of simple cuboidal or columnar types, whereas in inactive follicles, it was lined by very low simple cuboidal to squamous cells. Therefore, the present observations suggest that the low cuboidal epithelium encountered in early foetuses indicated poor secretory activity of thyroid hormones, while in the late foetal, prepubertal and pubertal stages, the high cuboidal or columnar epithelium indicate active thyroid activity (synthesis, secretion and resorp- tion of thyroglobulin to release thyroid hormones) and in the older pubertal animals showed flattened epithelium, suggesting that it is in a resting phase of thyroid activity.

The histometrical values showed that the foetal thyroid gland increased in follicular diameter, capsular thickness and follicular cell height throughout the gestation and postnatally with varying values. Significant variations $(\mathrm{P}<0.05)$ in structural size (follicular diameter, cell height and capsule thickness) of the thyroids were observed during development. The increased histometric parameters along with presence of colloid and other remarkable histological features during foetal development indicated that the foetal thyroids of all species studied are functional during gestation. This is in consonant with the observation and conclusion revealed by Thomas \& Nathanielsz (1983) in sheep and by Pickering (1968) in monkeys. The significant histometrical variations in the histometrical values amongst all the species studied is largely due to differences in the size and growth rate of the thyroid gland during the developmental period.

Immunohistochemically, calcitonin was detected in the parafollicular cells of studied foetuses and postnatal pigs and somastatin was only weakly detected in very few parafollicular cells of the pre-pubertal and pubertal thyroids. These somatostatinpostive cells were rarely encountered in sections. The study has shown that calcitonin is a good marker for identifying Ccells in the thyroid gland of pigs. It also means that parafollicular cells store calcitonin prior to birth in the breed of pigs used. The present report is supported by the detection of calcitonin in C-cells of thyroids from newborn to 7 month-old thyroids of pigs by Majdic et al. (1993) 
and Tsuchiya et al. (1984) that demonstrated calcitonin and somatostatin in adult pig thyroid and equally found somatostatin occurring in only very few parafollicular cells similar to the present report. Calcitonin was also demonstrated earlier in the C-cells of foetal cat thyroid gland (Titlback et al., 1987). Calcitoninpostive C-cells were detected in the thyroid glands of adult horse, pig, deer, mole and rat (Blähser, 1978). Somatostatin has also been shown to be present in few cells in the thyroids of humans, dogs and rats (Yamada et al., 1977). The present results showed marked variability in the distribution of calcitonin-positive cells with age and the number appeared to increase with age, similar to the observations in rats (Monsour et al., 1985). Calcitonin was originally discovered as a hypocalcaemic factor in several mammals. Early experiments demonstrated that calcitonin inhibited bone resorption and reduced efflux from isolated cat tibia and subsequent histologic and culture studies confirmed the osteoclast as its major site of action. Its potent antiresorptive effect and analgesic action have led to its use in treatment of Paget's bone disease, osteopososis and hypercalcemia of malignancy in humans (Inzerillo et al., 2002). Calcitonin is also a tumour marker in medullary thyroid carcinoma. Somatostatin is a protein distributed through the central and peripheral nervous system, and in peripheral tissues including endocrine pancreas, gut, adrenal gland, kidneys and thyroid gland. It is also produced by immune, inflammatory and certain cancer cells (England \& Atkin, 2002). It has been established that somatostatin inhibits TSH-stimulated thyroid hormone secretion as demonstrated both in vivo in mice and in man. Somatostatin has also been shown to inhibit TSH- stimulated cyclic AMP production in human thyroids (Ahren, 1991).

In conclusion, the study has shown that the thyroid gland varied in morphometry and histological structure and in the occurrence of some of its bioregulatory peptides during foetal and postnatal development of pigs. These variations may be related to adaptive physiological changes caused by nutrition, environment and even climatic factors. These changes should be taken into account in the interpretation of results in thyroid pathological and toxicological studies involving pigs of various ages.

\section{ACKNOWLEDGMENTS}

The authors are thankful for the technical assistance of Ms. Marie Smit and Dr. Sara Clift of the Immunohistochemistry Laboratory, Department of Paraclinical Sciences, Faculty of Veterinary Science, University of Pretoria, Onderstepoort Campus, South Africa.

\section{REFERENCES}

Agrawal, S. P., N. D. Khanna., V. K. Agrawal, \& P. K. Dwaraknath, 1986. Thyroid status of the male camel (Camelus dromedarius) during breeding and non-breeding season. Indian Journal of Animal Science, 57, 659-661.

Ahrèn, B. O, 1991. Regulatory peptides in the thyroid gland - a review on their localization and functioion. Acta Endocrinologica, 124, 225-232.

Badawy, Y. H., A. H. El-Keshaway, A. M. Ghallah, M. Abdou \& A. A. Salim, 1978. Histological and histochemical studies on the prenatal development of the thyroid gland in camel (Camelus dromedaries). Egyptian Journal of Histology, 6, 365375.

Blähser, S., 1978. Immunocytochemical demonstration of calcitonin-containing $\mathrm{C}$ cells in 
the thyroid glands of different animals. Cell \& Tissue Research, 183, 551-558.

Braverman, L. E. \& D. Coope, 2012. Werner and Ingbar's The Thyroid: A Fundamental Clinical Text, $10^{\text {th }}$ edn, Lippincott, Willians and Wilkins, London.

Blumenthal, H. T., 1955. Aging processes in the endocrine glands of various strains of normal mice: Relationship of hypophyseal activity to ageing changes in other endocrine organs. Journal of Gerontology (St. Louis), 10, 253-267.

Capen, C. C. \& S. L. Martin, 2003. The thyroid gland. In: McDonalds Veterinary Endocrinology and Reproduction, $5^{\text {th }}$ edn, eds M. H. Pineda \& M. P. Dooley, Iowa State Press, Ames, pp. 35-69.

Denef, J., A. Cordier, M. Mesquitta \& S. Haumont, 1979. The influence of fixation procedure, embedding medium and section thickness on morphometric data in thyroid gland. Histochemistry, 63, 163-171.

England, R. J. A. \& S. L. Atkin, 2002. Somatostatins and their role in thyroid cancer. Clinical Otolaryngology, 27, 120-123.

Fujita, H., 1975. Fine structure of the thyroid gland. Internatational Review of Cytology, 40, 197- 274.

Gaikwad, J. R., S. A. Dope \& D. S. Joshi, 2012. Histogenesis of developing human thyroid. Indian Medical Gazette, February, 57-61.

Huszenica, G. Y., M. Kulcszar \& P. Rudas, 2002. Clinical endocrinology of thyroid gland functions in ruminants. Veterinary Medicine - Czech, 47,199-210.

Igbokwe, C. O., 2013. Comparative morphology of the thyroid gland at various stages of development in some domestic animals, $\mathrm{PhD}$ Thesis, University of Nigeria, Nsukka, Nigeria.

Inzerillo, A. M., M. Zaidi \& C. Huang, 2002. Calcitonin. The other thyroid hormone (Review). Thyroid, 12, 791-798.

Janini, E. A., S. Ulisse \& M. D'Armento, 1995. Thyroid hormone and male gonadal function. Endocrine Reviews, 16, 443-459.
Kameda, Y., H. Oyama \& M. Horino, 1984. Ontogeny of immunoreactive somatostatin in thyroid C cells from dogs. The Anatomical Record, 208, 89-101.

Key, M. \& T. Boenisch, 2010. Antigen retrieval. In: Immunohistochemical Staining Methods, $4^{\text {th }}$ edn, ed M. Key, Dako Education Guide, California, U.S.A, pp. 41-45.

Krees, E., J. Samarut \& M. Plateroti, 2009. Thyroid hormones and control of cell proliferation or cell differentiation: Paradox or duality? Molecular Cell Endocrinology, 313, 36-49.

Majdic, G., C. Valliant, A. Pogark \& S. V. Baydek, 1993. Calcitonin and somatostatin-positive cells in the thyroid of pigs at different ages. Histochemistry and Cell Biology, 199, 481-484.

Marthur, M. L., 1971. Microscopic study of the thyroid gland of Asiatic water buffalo (Bubalis bubalus). American Journal of Veterinary Research, 32, 363-366.

McGeady, T. A., P. J. Quinn, F. S. Fitzpatrick \& M. T. Ryan, 2006. Veterinary Embryology, $1^{\text {st }}$ edn, Blackwell Publishers, Iowa, U.S.A, p. 291.

Mitskavitch, M. C., 1957. Glands of intestinal secretion in the developing birds and mammalian embryos, A publication of the Academy of Sciences of Moscow, U.S.S.R

Monsour, P. A., B. J. Kruger \& A. Barnes, 1985. Calcitonin cell population and distribution in the thyroid gland of the rat. Journal of Morphology, 183, 271-278.

Noden, D. M. \& A. DeLahunta, 1985. The Embryology of Domestic Animals: Developmental Mechanisms and Malformations, Williams and Wilkins, Baltimore, U.S.A, pp. 270-276.

Parker, R. O., P. E. Williams, F. X. Aherne \& B. A. Young, 1980. Histological structure of the thyroid gland in neonatal pig. Biology of the Neonate, 38, 120-125.

Pickering, D. E., 1968. Thyroid physiology in the developing monkey foetus (Macaca mullata). General and Comparative Endocrinology, 10, 182-190. 
Histological and immunohistochemical changes of the thyroid gland during the foetal and postnatal ...

Ranjan, R., A. Sharma, O. Singh \& N. Bansal, 2011. Histogenesis of the thyroid gland in the buffalo. Indian Journal of Animal Science, 81, 377-379.

Roy, K. S. \& R. C. P. Yadava, 1975. Histological and certain histochemical studies in the thyroid gland of Indian buffalo (Bubalus bubalis). Indian Journal of Animal Science, 45, 201-208.

Roy, K. S., R. P. Saigal, B. S. Nanda \& S. K. Nagpal, 1978. Gross histomorphological and histochemical changes in thyroid gland of goat with age. IV: Histomorphological study. Anatomische Anzeiger, 142, 80-95.

Rupik, W., 2011. Structural and ultrastrucural differentiation of the thyroid gland during embryogenesis in the grass snake Natrix natrix L. (Leiidosaura serpentis). Zoology, 114, 284-297.

Sawicki, B., 1995. Evaluation of the role of mammalian thyroid parafollicular cells (review), Acta Histochemica (Jena), 37, 171-179.

Sawicki, B., S. Siuda \& I. Kasacka, 1992. Microscopic strucuture of the thgyroid gland in the European bison. Acta Theriologica, 37, 171-179.

Schafie, M. M. \& M. M. Mashaly, 1974. Prenatal and postnatal thyroid development in bovines. Acta Anatomica, 87, 615-634.

Schally, A. V., 1987. Treatment of hormonedependent cancer with analogues of hypothalamic hormones: Experimental and clinical studies, Annals of the New York Academy of Sciences, 496, 602-607.

Soliman, S. M., T. M. Nabil, A. Z. ElKerdawy \& A. M. El-Bayomy, 2005. Development of the thyroid gland of the New-Zealand rabbit. Ben-Suef Veterinary Medicine Journal, 15, 1-8.

Swindle, M. M., A. Makin, A. J. Herron, F. J. Clubb \& K. S. Frazier, 2012. Swine as models in biomedical research and toxicology testing. Veterinary Pathology, 49, 344-356.
Thomas, A. L. \& P. W. Nathanielsz, 1983. The fetal thyroid. In: Current Topics in Experimental Endocrinology, vol. 5, Fetal endocrinology and Metabolism, eds I. Martini \& V. H. T. James, Academic Press, New York, pp. 97-110.

Tondini, T., 2007. Thyroid hormones in small ruminants: Effects of endogenous, environmental and nutritional factors. Animal, 1, 997-1008.

Tomonari, M., 1959. Histological studies on the mammalian thyroid glands. Archivum Histologicum Japonicum, 4, 497-523.

Titlback, M., J. Velicky \& H. Lhotova, 1987. Prenatal development of cat thyroid; Immunohistochemical demonstration of calcitonin in the C cells. Anatomy and Embryology, 177, 51-54.

Tsuchiya, T., Y. Shiomura, K. Suzuki, H. Nasai \& H. Tamate, 1984. Immunohistochemical study on the C-cells in pig thyroid glands. Acta Anatomica, 120, 138-141.

Venzke, W. G., 1975. Endocrinology. In: Sisson and Grossman's The Anatomy of Domestic Animals, $5^{\text {th }}$ edn, ed R. Getty, W. B. Saunders, Philadelphia, pp. 955-959.

Yamada, Y., S. Ito, Y. Matsubara \& S. Kobayashi, 1977. Imunohistochemical demonstration of somatostatin-containing cells in the human, dog and rat thyroids. Tohoku Journal of Experimental Medicine, 122, 87-92.

Paper received 30.09.2014; accepted for publication 22.01.2015

\section{Correspondence:}

Casmir Onwuaso Igbokwe,

Department of Veterinary Anatomy,

Faculty of Veterinary Medicine,

University of Nigeria,

Nsukka, Nigeria

phone: +234-8034930393

e-mail: casmir.igbokwe@unn.edu.ng 